\title{
Two Centuries of Looting and the Grand Nazi Book Burning. The Dispersed and Destroyed Libraries of the Polish-Lithuanian Commonwealth: Historical Losses and Contemporary Attempts at
} Reconstruction

\author{
Tomasz Nastulczyk
}

While losses of early printed books and historical libraries were significant in Western Europe, researchers from Central and Eastern Europe must cope with so many lost and dispersed collections that they may sometimes ironically call themselves 'specialists in nonexistent things'. The history of collections from the lands of the former Polish-Lithuanian Commonwealth is one of the most telling examples: here historical events during the eighteenth, nineteenth and twentieth centuries left only a few historical libraries untouched.

Of course, cases of library looting in the territories of Commonwealth had also happened before this. The most eminent case is the organized plunder of cultural goods, among them libraries, by the Swedish army during the seventeenthcentury wars. This 'war booty' can now be found in various places in Sweden: in Uppsala, in Strängnäs and in Stockholm. Most recently, in 2004, an important collection of early printed Polish books was discovered in Skokloster Castle. ${ }^{1}$ These collections are generally well preserved and accessible to researchers. From the historical perspective, the Swedish pillaging paradoxically helped to preserve many books which would probably have been lost in the course of history had they stayed in place.

The second half of the eighteenth century, which brought the collapse of the Polish-Lithuanian Commonwealth and the partition of its lands between Russia and (on a minor scale) Austria and Prussia, started a process of continuous looting of the numerous existing libraries. The Russian government confiscated entire collections not only because of their value, but also as an act of repression, in an attempt to destroy the local culture. The most eminent among the confiscated libraries was the Załuski Library (the first Polish national

1 Maciej Eder, Elisabeth Westin Berg, and Dariusz Chemperek (eds.), Polonika ze zbiorów zamku Skokloster. Katalog (Warszawa: Wydawnictwo Neriton, 2008). 
library), opened in Warsaw in the middle of the eighteenth century and sent to the Imperial Public Library in Saint Petersburg after the failure of the Polish uprising in 1794. Two other public libraries, namely, the Library of the Warsaw Society of the Friends of Learning and the Warsaw University Library, were confiscated after 1831. Most of the private collections also suffered a similar fate, among them the Library of the Radziwiłł Dukes in Nieśwież (now Nesvizh, Belarus).

To make matters worse, the authorities of the rapidly modernizing Russia would send large parts of the confiscated libraries to every corner of their empire. New academic institutions were opened in Central Asia, Finland, and even deepest Siberia; the ransacked Polish libraries provided them with something to fill their shelves. Some of the books even went back to Russiangoverned Warsaw. These transfers were poorly documented, and large sections of confiscated collections were practically lost - traces of the transfers are dim, but the books may still be somewhere, either in the inaccessible, unrecognized and uncatalogued parts of the collections in Saint Petersburg and Moscow or in local academic institutions which used to belong to the Russian Empire. In addition, the Austrian, Prussian and Russian governments embarked on the organized suppression of Catholic monasteries and cloisters, causing their vast libraries to be confiscated and in many cases destroyed as worthless. The political and ideological context of the suppression varied, but in all cases the monastic collections were considered to be merely a group of obscure, old religious writings with no value to the modern, enlightened state. Attempts to reconstruct the original content of certain monastic collections now offers one of the most interesting tasks for Central and Eastern European researchers.

The emergence of an independent Poland in 1918 initiated the consolidation of the dispersed historical collections. The National Library in Warsaw was founded, and the Polish government managed to retrieve several parts of the historical collections confiscated during the eighteenth and nineteenth century from Russia, including the Załuski library. Unfortunately, the beginning of the second world war brought a rapid end to this revival.

Let me start with some basic data, which, however, should be regarded as an estimate. Documentation of war losses in Poland must be based on secondary sources of various quality. In pursuing this question different researchers follow different methodologies, and their studies sometimes vary in points of detail. The exact numbers will probably never be known, despite their best efforts. For all this we may say with a certain degree of authority that the overall scale of losses from Polish public libraries in the second world war is somewhere in the region of $70 \%$ of their pre-war stock. Public libraries lost about $89 \%$, and academic and professional libraries about 50\%, including, unfortunately, 
their most valuable collections. ${ }^{2}$ The documented number of lost incunabula, early printed books from before 1801, manuscripts, musicalia, theatralia, maps and drawings is estimated to be over two million items. ${ }^{3}$ As far as the incunabula are concerned, the war losses have been documented in the central catalogue of the incunabula in Polish libraries. ${ }^{4}$ It registers over 2,300 lost bibliographical items in about 4,600 copies. ${ }^{5}$

The biggest and the most painful loss stemmed from the Nazi destruction of books in Warsaw in 1944. The unfortunate reorganization of the city libraries after 1939 resulted in the most valuable special collections of Warsaw's libraries, namely the National Library, the Krasiński Family Library and the Warsaw University Library, being brought together under one roof. Reorganization was rather a continuous process than a single act. German officials most probably tried to prove their usefulness to the Nazi authorities and to avoid military service by initiating such a huge operation, so the books were in constant movement. ${ }^{6}$ Moreover, special collections, among them the Załuski Library, had not been fully described before the war, and the existing documentation was mostly burnt together with them. Because of this, the total amount of special collections material gathered by the Nazis in the building of the former Krasiński Family Library can only be roughly estimated at between 300,000 and 400,000 volumes (more detailed studies suggest 388,000 to 400,000 volumes). ${ }^{7}$ These collections included about 80,000 books printed before $1801 .{ }^{8}$ The special collection from the National Library formed the largest portion of the rare

2 Barbara Bieńkowska, 'II wojna światowa: wstępny bilans strat bibliotek polskich', Cenne, bezcenne, utracone, 3/72 (2012), pp. 10-11, here at p. 11 .

3 Bieńkowska, 'II wojna światowa: wstępny bilans strat bibliotek polskich', p. 11.

4 Alodia Kawecka-Gryczowa etc., 'Incunabula in catalogo generali ante mensem Septembrem a. 1939 composito enumerata, post autem annum 1945 in Polonia non reperta - cum indicibus annexis', in Alodia Kawecka-Gryczowa etc. (eds.), Incunabula quae in bibliothecis Poloniae asservantur, vol. 2, Addenda. Indices (Wrocław-Warszawa-Kraków: Zakład Narodowy imienia Ossolińskich - Wydawnictwo, 1993), pp. 175-510.

5 Alodia Kawecka-Gryczowa, 'Wstęp', in Kawecka-Gryczowa etc. (eds.), Incunabula quae in bibliothecis Poloniae asservantur, vol. 2, p. Xv; Michał Spandowski, 'Inkunabuły utracone. Z prac nad Centralnym Katalogiem Inkunabułów w Polsce', Cenne, bezcenne, utracone, 3/72 (2012), pp. 16-18, here at p. 18.

6 The reorganization process was described in great detail by Andrzej Mężyński, 'Zbiory na Okólniku. Wrzesień 1939 - październik 1944', in Halina Tchórzewska-Kabata (ed.), Droga do Okólnika. 1844-1944 (Warszawa: Biblioteka Narodowa, 2005), pp. 113-147.

7 Hanna Łaskarzewska, 'Straty Okólnika w czasie powstania warszawskiego i po jego upadku', in Halina Tchórzewska-Kabata (ed.), Droga do Okólnika. 1844-1944, (Warszawa: Biblioteka Narodowa, 2005), pp. 173-174; Mężyński, 'Zbiory na Okólniku', p. 136.

8 Mężyński, 'Zbiory na Okólniku', p. 136. 
material gathered in this way. It contained over 2,00o incunabula, 6,70o books from the sixteenth century, 12,000 books from the seventeenth century, and 35,000 books from the eighteenth century. ${ }^{9}$ The catalogues were also lost, but one of the pre-war Polish librarians, Alodia Kawecka-Gryczowa, had managed to copy the registers of incunabula in previous years, 'just in case', without the Nazi authorities knowing anything about it. Her notes are now the most important source of information about the destroyed collection. ${ }^{10}$

On 5 September 1944, during the Warsaw uprising, the building was bombed and the collections located on the upper floors burnt, but the most important collections, hidden in the basements, were still safe. ${ }^{11}$ After the defeat of the uprising in October 1944, when Warsaw became deserted, the Nazi troops started the organized process of burning the city to the ground. The invaluable collections were set on fire by the German Brandkommando before 14 October 1944 and were left burning for a few days. ${ }^{12}$ The remains suggested that the separate collections were set on fire methodically, one after another. ${ }^{13}$ Destruction was almost total, and only a very small group of manuscripts was recovered from the ruins. ${ }^{14}$ The Nazis also burnt the entire stores of the Warsaw Public Library and destroyed several minor public and private collections in the city. Moreover, they threw incendiary grenades into the Zamoyski Family Library, which resulted in the destruction of about 10,00o books printed before 1801, maps and drawings, together with catalogues..$^{15}$

After 1945 Polish researchers were confronted by the fact that the majority of early printed books had been destroyed or were virtually inaccessible. The newly drawn borders and population transfers cut off Polish researchers from many historical libraries that now belonged to the Soviet Union. On the other hand, Soviet political pressure made it very difficult to support international academic contacts, and the local Russian, Ukrainian, Belarussian and Lithuanian librarians were discouraged from working with these materials. However, the

Alodia Kawecka-Gryczowa, 'Wstęp', in Alodia Kawecka-Gryczowa etc. (eds.), Incunabula quae in bibliothecis Poloniae asservantur, vol. 1 (Wrocław-Warszawa-Kraków: Zakład Narodowy imienia Ossolińskich - Wydawnictwo, 1970), p. xxxi; Kawecka-Gryczowa, 'Wstęp' in Kawecka-Gryczowa etc., Incunabula quae in bibliothecis Poloniae asservantur, vol. 2, p. XIX, footnote 11; Mężyński, 'Zbiory na Okólniku', p. 136; Spandowski, 'Inkunabuły utracone', p. 18.

10 Spandowski, 'Inkunabuły utracone', p. 17.

11 Łaskarzewska, 'Straty Okólnika', pp. 158-159.

12 Łaskarzewska, 'Straty Okólnika', p. 163.

13 See the relation of Tadeusz Makowiecki, quoted by Łaskarzewska, 'Straty Okólnika', p. 166.

14 Łaskarzewska, 'Straty Okólnika', pp. 170-171.

15 Łaskarzewska, 'Straty Okólnika', p. 162. 
dissolution of the Soviet Union forty years later created new opportunities. The new possibility of international cooperation caused Polish, Russian, Ukrainian, Belarussian and Lithuanian researchers to dig frenetically into their collections. The University Libraries in Odessa and in Kharkiv prepared catalogues of their early printed Polish books in cooperation with my home institution, the Polish Bibliography Research Centre. ${ }^{16}$ The University Library in Nizhyn (Ukraine) has already described their collection, which had been sent there from the Warsaw University Library in the nineteenth century. ${ }^{17}$ When one of our Russian colleagues discovered about 1,200 early printed Polish books which had been stored as 'war booty' in the State University Library in Moscow since the war, we managed to prepare an official exhibition despite the uncertain legal status of this collection. ${ }^{18}$

I would like to describe one similar project in greater detail. Together with researchers from Russia, Finland and Poland, the Polish Bibliography Research Centre has attempted to trace and describe Polish books confiscated by Russian soldiers from the first library of the Radziwiłł Dukes in Nieśwież at the end of the eighteenth century. ${ }^{19}$ The term 'first library' is related to the complicated history of the Nieśwież collections. In 1749, one of the dukes brought together the old family collections from the sixteenth and seventeenth centuries under

16 Hanna Volodymyrivna Velykodna, Ol'ha Leonidivna Lyashenko etc., Pol's'ki starodruky z kolektsiy universytets'koyi biblioteki. Kataloh. Starodruki polskie ze zbiorów biblioteki uniwersyteckiej. Katalog (Odessa: Odes'kyy natsional'nyy universytet, 2012); Kolektsiya pol's'kykh ridkisnykh vydan' u fondi Tsentral'noyi naukovoyi biblioteky imeni V.N. Karazina (Kharkiv, edition-in-progress).

17 Oleksandr Serhiyovych Morozov etc., Starodruky XVI - pershoyi polovyny XVIII st. z kolektsiyi 'Polonica' biblioteky Nizhyns'koho derzhavnoho universytetu imeni Mykoly Hoholya. Kataloh (Nizhyn: Tov Hidromaks, 2010); Oleksandr Serhiyovych Morozov, Starodruky z kolektsiyi 'Polonica' biblioteky Nizhyns'koho derzhavnoho universytetu imeni Mykoly Hoholya. Druha polovina XVIII - pochatok XIX st. Kataloh (Nizhyn: Vydavnytstvo NDU im. M. Hoholya, 2012).

18 Stanisław Siess-Krzyszkowski and Irina Leonidovna Velikodnaya, Polskie książki i rękopisy w zbiorach Biblioteki Naukowej Państwowego Uniwersytetu im. M.W. Łomonosowa w Moskwie. Katalog. Pol'skiye redkiye knigi i rukopisi v fondakh Nauchnoy biblioteki MGU im. M.V. Lomonosova. Katalog (Moscow: Nauchnaya biblioteka MGU im. M.V. Lomonosova, 2005).

19 Stanisław Siess-Krzyszkowski etc., Katalog starych druków Biblioteki Ordynacji Nieświeskiej Radziwittów w zbiorach Bibliotek: Rosyjskiej Akademii Nauk w Sankt Petersburgu, Państwowego Uniwersytetu im. M.W. Łomonosowa w Moskwie, Narodowej Finlandii w Helsinkach i Uniwersyteckiej w Warszawie. Druki polskie XVI-XVIII w. (Internet database), (Kraków: Centrum Badawcze Bibliografii Polskiej Estreicherów UJ), online: <http://www .estreicher.uj.edu.pl/bazy_bibliograficzne/index.php/75>. 
one roof. ${ }^{20}$ This library, about 15,000 volumes, was pillaged in 1772 by the Russians. The Radziwiłł family quickly rebuilt their collection and created a second library, only to see that confiscated by the Russians in 1813 after the unfortunate Napoleonic invasion of Russia. The family started again and a third Nieśwież library was organized. It remained intact till the first days of the second world war, when the Soviet Union invaded the eastern Polish territories and confiscated everything.

Let us go back to the history of the first library. 15,000 volumes from the Nieśwież collection were transferred to the Library of the Imperial Academy of Sciences in Saint Petersburg and carefully catalogued. This catalogue registered 9,673 titles, and was the base for our project, together with the original Polish registers for the sub-collections (i.e. personal book collections of certain family members which supplemented the library). ${ }^{21}$

The collection soon became dispersed. In 1814 over a thousand books were sent to Moscow University Library to replace the collection burned in 1812. In 1829 the newly opened Helsinki University Library received a similar amount of books from the Nieśwież collection. These mostly came from Saint Petersburg, but some of them bear the stamps of the Moscow University Library. ${ }^{22}$ Then, in the 1830s, the collection remaining in the Library of the Imperial Academy of Sciences was divided into groups according to language criteria. Publications in Polish were at first transferred to the Russian books department, and then divided between the Slavic books department and the rare books department. The rest, including Polish publications in Latin, were placed in the foreign books department. ${ }^{23}$ In the following years, 37,00o items from the Library of the Academy of Sciences in Saint Petersburg were transferred to the University

2o The history of the first Nieśwież library was described in detail by Stanisław SiessKrzyszkowski, 'Pierwsza Biblioteka Ordynacka w Nieświeżu i jej znaki własnościowe (na podstawie bazy danych: Katalog starych druków Biblioteki Ordynacji Nieświeskiej Radziwiłłów. Druki polskie XVI-XVIII wieku)', in Rocznik Biblioteki Narodowej, vol. 41, 2011, pp. 135-160.

21 Catalogus Bibliothecae Radivilianae, Archive of the Russian Academy of Sciences in Saint Petersburg, f. 158, op. 1, Nos. 226-227. For the entire list of archival sources and full bibliography of the project, see: Siess-Krzyszkowski etc., Katalog starych druków Biblioteki Ordynacji Nieświeskiej Radziwittów (Internet database). See also: Rafał Jankowski, 'Przegląd materiałów źródłowych do historii i rekonstrukcji radziwiłłowskiego księgozbioru w Nieświeżu, zgromadzonych w Archiwum Głównym Akt Dawnych w Warszawie', in Rocznik Biblioteki Narodowej, vol. 41, 2011, pp. 95-106, and Siess-Krzyszkowski, 'Pierwsza Biblioteka Ordynacka w Nieświeżu', p. 147.

22 Siess-Krzyszkowski, 'Pierwsza Biblioteka Ordynacka w Nieświeżu', pp. 148-149.

23 Ibid., pp. 149-150. 
Library in Warsaw, among them numerous early printed books from the first Nieśwież library. There are also dim traces of a similar donation to the Museum of Antiquities in Vilnius, but no volumes have been found thus far. ${ }^{24}$ Many duplicates were also put on sale, and so single books from Nieśwież may now be found in many academic libraries, for instance the University Library in Kharkiv. ${ }^{25}$ Finally, the vast foreign books department of the Library of the Academy of Sciences in Saint Petersburg was heavily damaged during a fire in 1988 , and its losses have not been fully documented. ${ }^{26}$

Our international research team managed to locate 767 items from Nieśwież in Saint Petersburg, 76 items in Moscow, 820 items in Helsinki, and over 23 items in Warsaw. Identification was based on old ownership inscriptions and the aforementioned registers. Among these we have found 911 Polish books printed before 1801 in 766 volumes, plus 64 volumes of duplicates. ${ }^{27}$

The results of this project are presented in the form of an open-access database, which is continuously expanded; study is still in progress. We have not managed to access the rare books and the foreign books departments in Saint Petersburg, and we now have to wait till the current political situation in Russia and Ukraine calms down. Provenance research in Warsaw still continues. The problem of the mysterious donation to Vilnius has still to be fully explained.

Book researchers in Central and Eastern European face a serious task: to reconstruct the shape and history of lost historical collections not only for descriptive purposes, but also in an attempt to rediscover some of the lost books in the vast amounts of materials that have recently surfaced and are not yet fully described. The prospects are very promising, but the amount of work to be done requires constant cooperation between numerous Russian, Ukrainian, Belarussian, Lithuanian and Polish scholars. Knowledge exchange and experience sharing are just as important as practical support in accessing collections or publications that are hardly accessible. The current war in eastern Ukraine and its political, social and financial consequences make this work much harder, but the spirit of professional solidarity is strong and hopefully sooner or later full-scale cooperation will be possible again.

\footnotetext{
24 Ibid., pp. 149-150.

25 Ibid., p. 150.

26 Ibid., p. 150.

27 Siess-Krzyszkowski etc., Katalog starych druków Biblioteki Ordynacji Nieświeskiej Radziwittów (Internet database).
} 